\title{
Depicting the Orient in Wilkie Collins' The Moonstone
}

\author{
Amna Matar Al-Neyadi \\ English Literature Department, United Arab Emirates University \\ P. O. Box 15551, Al-Ain, United Arab Emirates \\ E-mail: Aalneyadi@uaeu.ac.ae
}

Received: 20-04- 2015

Accepted: 25-07- 2015

Advance Access Published: August 2015

Published: 01-11- 2015

doi:10.7575/aiac.ijalel.v.4n.6p.181

URL: http://dx.doi.org/10.7575/aiac.ijalel.v.4n.6p.181

\begin{abstract}
Nineteenth century Britain witnessed an increased interest with the Orient, largely as a result of the imperial expansion that reached its peak during that time. India was one of the main Oriental interests of the Victorians because of the political, commercial, religious and scientific passion of the nineteenth century people in India. For that reason, various Victorian authors who wrote about India were mostly characterized as being orientalist and writing in a biased way. One such example of this was Joseph Rudyard Kipling. This, as Edward Said explains, was because nineteenth century writers were aware of the empire's authority. However, I propose that Wilkie Collins tended to have a positive attitude towards the Orient in his novel The Moonstone and towards the Brahmins specifically, which is an attitude that deviates from what is currently known about him. To argue this, the paper will analyse the narrative techniques and the reflection of some of the characters' attitudes towards the Orient that Collins adopts in his novel in order to allow Victorian readers to challenge the stereotyped beliefs of the Orient. It will also comment on Collins's employment of the sensational sub-genre particularly to draw his own attitude of the Orient.
\end{abstract}

Keywords: Brahmins, India, Sensational Novel, Victorian Orientalism

\section{Introduction}

\subsection{Introduce the Problem}

The British colonialism of the nineteenth century is also associated with orientalism since the latter has a political dimension, too. Victorian England was interested in the Orient for various reasons. One was for the commercial reason that was allied with East India Company and helped in increasing immigration to India whom viewed India as a mysterious place which seized "British imaginations" to write about it and created a sense of curiosity to know more about this place (Peers, 2013, p. xi). Another was the religious passion that allowed scholars to travel to the Orient, though there were some historians, such as James Mill, criticized Indian bond with religion since it is part of feudalism and backwardness that needed to be obliterated. Consequently, many authors and poets became engaged with the Orient and portrayed India in their works. One example is Wilkie Collins' novel The Moonstone and which is commonly agreed to be one of his best works. By investigating Collins' approach to the Orient in the novel, I suggest that Collins tended to have a positive attitude toward the Orient and specifically toward the Brahmins. This is revealed through his narrative technique and the portrayal of the main English characters' attitude in the novel towards the Orient.

\subsection{Novel Summary}

Wilkie Collins novel The Moonstone revolves around the robbery of a Hindu gem which represents the God of the moon. The plot starts when Colonel John Herncastle kills three Brahmins, who were in charge of protecting the

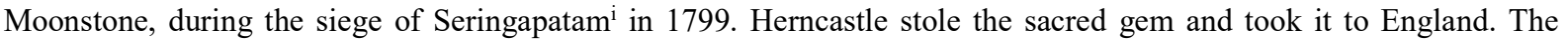
Brahmins promise that the 'The Moonstone will have its vengeance yet on you [Herncastle] and yours [any one that obtains it]!' (Collins, 1998, p. 14).

Before Herncastle's death, he asks his executer to give the Moonstone to his niece Rachel on her eighteenth birthday. At Lady Verinder's (Rachel's mother) house in England the plot becomes more complicated. On Rachel's birthday Franklin Blake (Lady Verinder's nephew) gives the Diamond to Rachel even though Franklin, Lady Verinder, and Betteredge are all aware of the curse. On the following day, the Verinder household discovers that someone has stolen the Diamond. In order to find the thief, Franklin asks some of the guests to write what they know about the events surrounding the disappearance of the Moonstone. The various narrations account by several characters help to identify Godfery as the perpetrator.

\section{Victorian Orientalism}

Orientalists started with the translation of Oriental works so that the colonizer would be able to understand the people of the colonies (Sered, 1996). After translating the Orients' works the orientalists started to write about the Orient. Therefore, Orientalism became "a style of thought based upon an ontological and epistemological distinction made between "the Orient" and (most of the time) "the Occident" (Said, 1978, p. 2). These writings were produced in order to continue to impose the authority of the West upon the East. Raymond Schwab comments that in nineteenth-century 
England, Orientalism witnessed an "intellectual movement ... called the Oriental Renaissance" (Al Dabbagh, 2010 , p. 8). Consequently, the Oriental in the West started to have "new dimensions and deeper meanings" (A1 Dabbagh, 2010, p. 8). Heehs (2003) declared that nineteenth century orientalism has two sides, scholastic and romantic. The romantic side is more likely to present the Orient in a positive way and is associated with Germany. On the other hand, scholastic orientalism is connected to Said's point of view of the Orientalist. Said demonstrates that nineteenth century British writers were aware of the Empire's authority. Such awareness gave these writers the opportunity to view the others as inferior and different from them (Said, 1978)

\section{Collins's Techniques in Depicting the Orient}

\subsection{Roots of Orientalism in the Detective and Sensational Fiction}

The Moonstone is regarded as one of the first novels that paved the way to the detective genre. T. S. Eliot labeled the novel as "the first, the longest, and the best of the modern English detective novel" (Collins, 1998, p. vii). He adds as well that it's "a genre invented by Collins and not by Poe" (as cited in David, 2001, p. 179). The sensational novels deal with adultery, theft, kidnapping, insanity, bigamy, forgery, seduction and murder. These themes are portrayed in "ordinary, familiar and often domestic settings" (Cook, 2014, p. 6). In so doing, it destabilizes the notion of calmness and stability that the Victorians were aiming to emphasize in their households.

The sensational novels have an orientalist setting which creates the idea of foreignness and the 'Other'. The middleclass, during the Victorian period, represented an ideal harmony compared to other classes. The Industrial Revolution allowed them to achieve a "coherent body" that permitted them to play a significant role in politics and the economy (Loftus, 2011, para. 1). "The success of the middle-classes in the Victorian period can be seen in their ability to universalise a set of principles based on individuality and progress" (Loftus, 2011, para. 5). This harmony was also reflected in their household where the role of each member was rigorously determined. Therefore, the idea of foreign behaviour or behaviour out of the norm threatened the middle-class, since they expected clarity and calmness. Such principles and the fixedness of ideas made the middle-class believe that in fiction sensational settings were something out of their society.

According to Marty Roth, "detective fiction is 'always' engaged in a veiled form of colonial discourse" (Lightwalla, 2010 , p. 291). This is as a result of the elements on which the detective novel is based. One of them is that the detective novel is built on a mystery. Orientalism appeared because the West feared the East. Consequently, the Orient, for the orientalists, was viewed as a mystery that needed to be comprehended and resolved (Al Dabbagh, 2010). The sensationalist novel is a subgenre of the detective novel. It involves various elements which help to serve the idea of orientalism that the novel deals with. The sensationalist novel tries to deliver "violent and thrilling action, astonishing coincidences, stereotypic heroes, [and] heroines" (Brantlinger, 1982, p. 5). The Moonstone opens with the siege of Seringapatam and the death of the three oriental characters who promise punishment for the Diamond's burglars. The curse of the Brahmins (orient) becomes the source of the plot evolvement as well as the source for problems for the Verinder family. One example of the violence that follows this curse is the suicide of Rosanna. After stealing the Diamond, mystery envelopes the Verinder household, where some doubts start to surround certain characters and one of them is Rosanna which drives her to commit suicide as a consequent. This is to call another element that the incidents of the genre evoke, that is the occurrence of "astonishing coincidences" (Brantlinger, 1982, p. 5). It is employed to create more mystery and suspense towards the person who committed any of the subject matters that sensational novels deal with. In this novel, coincidence is represented through the theft of the Moonstone by Franklin in Rachel's birthday which will be explained in the opium section. This shows the innocence of the Orient and the immoral accusation of the British household against the three Brahmins.

Another element of the sensational novel, according to Brantlinger, is that the genre questions "virtue and domesticity" (Brantlinger, 1982, p. 5). This point is employed in this novel to serve both the actions of the Western and Oriental characters. Western virtue is questioned by the reader's attitude toward John Herncastle's behavior. One is the crime which he commits in order to steal the spiritual stone of the Hindus. This behavior shows the violation of the colonizer towards the sacred symbol of the Orient. The other virtue that the reader question is Herncastle's insistence to give his niece Rachel the Moonstone on her eighteenth birthday though he knows the curse of the gem would condemn anyone who owns it. Godfrey, Lady Verinder's nephew, is the other character whose virtue is questioned. He pretends to be a philanthropist; however he is in fact embezzling the charity's money. What is more, he marries an heiress (Rachel) so he can have power and control her fortune. On the other hand, Oriental virtue is questioned when the Brahmins insist on retrieving the Moonstone even if the only way to do so is to commit a crime. Questioning the virtue of both the English characters and the Orient is a method Collins uses to give the readers a chance to judge such representation, which is elaborated in the following paragraphs.

The sensational novel also "exercise[s] a corrupting influence on higher culture" (Brantlinger, 1982, p. 7-8). Collins demonstrates this in his novel by portraying the gem's curse that reaches English society. Colonel Herncaslte becomes an outcast after his return from India and Lady Verinder refuses to meet him. The curse of the Moonstone follows Lady Verinder's household after Herncastle's request to give Rachel the gem on her birthday. This creates stressed relations between the members who attended Rachel's birthday in order to detect the gem's thief. Such incidents show how the Moonstone, which embodies India and represents the Orient, has corrupted the peaceful English house.

The plot of this novel does not show the corruption of an inferior culture upon high culture only but also "lead[s] to the unmasking of extreme evil behind fair appearance" (Brantlinger, 1982, p. 11). The process of detection that involves 
several narrators helps to reveal Godfrey's character. He pretends to be benevolent under the mask of charity. However, Ms. Clack (his helper) condemns him when she sees his relationship with Rachel. Moreover, the narration reveals that Godfrey is malicious when he insists on marrying heiress for the sake of their money. Such employment enforces Collins's neutral perspective towards cultures by showing that there is no perfection in any one particular culture. Collins uses this technique in order to contrast between cultures and to engage the reader in giving their point of view of either culture.

\subsection{Britain and Colonial India}

Edward Said emphasizes in his book Orientalism that "modern Orientalism has been an aspect of both imperialism and colonialism" (Said, 1978, p. 123). Therefore, this part of the paper focuses on colonialism and its relation to orientalism. Trade in India before the nineteenth century had attracted various conquerors, arguably starting with Alexander the Great in 327-326 CE. This was followed by the Portuguese, the Dutch, and the British, respectively. The British trade in India began at the end of the $16^{\text {th }}$ century. However, the colonial era of India began after the Battle of Plassey 1757, when the British Company was appointed to have control on the Bengal province and extended later to have control upon the Indian sub-continent ("Battle", 2013). By the middle of the nineteenth century, most parts of India were under the control of the British Empire. The importance of the colony increased because of its "importance to the British economy" (Hobsbawn, 1989, p. 69). Therefore, India became the "brightest jewel in the imperial crown" (Hobsbawn, 1989, p. 69).

The Indian society in general was seen by the British as a collective community and a place of spirituality of many sects. The British found "all group differences ... as dangerous separatisms" (Jouhki, 2006, p. 8). This way of life did not satisfy the British since they thought that human purpose in life was "to exploit the earth's resources" (Särkkä, 2009 , p. 55). Therefore, the British found it their responsibility to civilize India and to emancipate its people. For them, "Imperialism sought to justify itself as the "sane civilization of lower races"” (Särkkä, 2009, p. 152). Through this perspective, Britain defended its colonization of India since "Indians as a body had no political claims to inviolability" (Särkkä, 2009, p. 152). British colonialism started to introduce new jobs in cotton mills and new crops in agriculture such as coffee, tea, jute, indigo and tobacco.

In Wilkie Collins' novel The Moonstone, colonialism is represented on various levels. Betteredge embodies the imperial character who adopts colonial thoughts and beliefs. He believes in the superiority of his own race and represents that in various ways. Although the novel focuses mostly on the English household, Betteredge's deep engagement with Daniel Defoe's Robinson Crusoe emphasizes his imperial attitude. According to Fausett this novel used to be viewed as "modern individualism" during the eighteenth century. However, for the Victorians, "it was 'a model for thought and conduct' appropriate for colonial purposes and became a guide for the families emigrating to the colonies where they expected to prosper in isolation" (Umunç, 2000). Betteredge's adherence with the novel is more than mere entertainment. He demonstrates in chapter one of the first period narration that no one wrote a book such as Robinson Crusoe before and no one is going to write a book that carries its quality again. Moreover, he shows that this book is his guide whenever he needs consultation on serious matters.

Such a book as Robinson Crusoe never was written, and never will be written again. I have tried that book for years - generally in combination with a pipe of tobacco - and I have found it my friend in need in all the necessities of this mortal life. When my spirits are bad - Robinson Crusoe. When I want advice - Robinson Crusoe. In past times when my wife plagued me; in present times when I have had a drop too much Robinson Crusoe. I have worn out six stout Robinson Crusoe with hard work in my service. On my lady's last birthday she gave me a seventh. I took a drop too much on the strength of it; and Robinson Crusoe put me right again. Price four shillings and sixpence, bound in blue, with a picture into the bargain. (Collins, 1998, p. 22-3)

From these lines, Robinson Crusoe epitomizes a way of life for Betteredge. It is the one that supplies him with life, energy and reason. It is the one from whom he demands support, not only for 'mortal life' but also spiritually. Simply put, this book replaces the Bible in Betteredge's situation. What is more, Betteredge tries to gain the reader's sympathy by word choices in this part of his narration in order to gain their advocacy with his belief in this book. Betteredge not only uses words such as 'necessities', 'spirit', and 'strength', but also encourages the readers to have a copy by quoting the low price of the novel.

\subsection{Opium and Tobacco as a Connotation of the Orient}

One of the effects of British colonialism on India that has its roots in the Orient is the spread of opium. Trade of opium in the East went through several stages till it become popular in India. Arab traders introduced the opium poppy "into India and some parts of southwestern China" in the $7^{\text {th }}$ century A.D. At that time it was used as a treatment for illnesses. Opium smoking, however, was first provided to Chine in the 1500s by the Europeans. By the 1700s, the British East India Company became the first opium supplier in Asia. Later, during the 1800 s, each European Colony had an opium den (McCoy, 1972). Opium became popular not only in the colonies but also in the colonizers' land. In Britain, before the end of the $18^{\text {th }}$ century, opium was used as a painkiller for diseases such as gout, rheumatism and neuralgic pains. However, by the end of the $18^{\text {th }}$ century and early $19^{\text {th }}$ century opium became "epidemic" between the different classes of English society. What increased the British involvement with opium is Dr. Webster's $\mathrm{s}^{\mathrm{ii}}$ recommendation of Calcutta's opium, since it was the better than Turkish opium. Therefore, Britain was permitted to "extend the cultivation of the opium poppy in India" by 1830 . This allowed increasing the British income from the sale of opium since Bengal started 
to supply Britain with $£ 981,293$ in revenue from opium by 1832 . What is more, both Opium Wars, $1839-42$ and $1856-$ 58 , were ultimately fought to protect the income and trade of opium (Clarke, 1999). On the other hand, tobacco had been introduced to the royal court in India by the Portuguese and it was used for "barter trade" (Reddy, 2004, p. 5). However, "India's tobacco production and consumption" flourished by the British dominance of India (Reddy, 2004, p.5).

Wilkie Collins was one of the many who became addicted to opium. Collins started to suffer from rheumatic gout pain when he was thirty years old. Consequently, he resorted to laudanum (opium and alcohol) in order to treat his pain. This was during the time of writing The Moonstone. This, therefore, becomes haunted with the image of opium which plays a great role in the novel. One reason that can be drawn from Collins's emphasis on opium is that this novel is considered an orientalism novel and opium originated in the Orient. According to Bronagh Clarke, "to the late nineteenth century mind the image of opium was very much entangled with concepts of the Orient, of deviance, and sexual licentiousness in an Eastern context". This attitude towards drugs differs from what people used to know about it as "pharmaceutical panacea" at the beginning of the century (Clarke, 1999). Wilkie Collins novel is one of those novels which were affected by the new attitude since it was already published by then.

In The Moonstone, both opium and tobacco have a significant role for indicating the Orient. Opium, which is a connotation of the Diamond curse, is reflected in The Moonstone in various dimensions. The first time it is mentioned is in relation to Colonel Herncastle. After returning from India, the Brahmins' curse leads him to experience a "solitary, vicious, underground life" (Collins, 1998, p. 44). This life led him to end up "smoking opium" and to be "seen carousing and amusing himself among the lowest people in the lowest slums of London" (Collins, 1998, p. 44). What is more, the Colonel "had dogs, cats, and birds to keep him company; but no human being near him" (Collins, 1998, p. 49). Herncastle's relationship with opium had turned him into outcast rejected by people, as Franklin portrayed him as a "notorious opium-eater" (Collins, 1998, p. 48).

Herncastle's addiction to opium was just after his arrival from India. People of his own class disdained him which led to his being alone. Betteredge narrates that "after his return to England, I myself saw him, face to face ... there I found the Colonel, wasted, and worn, and old, and shabby, and as wild and as wicked as ever" (Collins, 1998, p. 44). Opium is therefore viewed to be the curse of India on Herncastle, since he stole the gem. Moreover, it is the curse of the colonies. Imperial England considered itself superior to the Orient which was viewed as being backward and in need of education. Consequently, Herncastle's coexistence with Orientals, who were considered a lower race, makes him live in a life of deviance confined with people of "the lowest slums in London" (Collins, 1998, p. 44).

During the nineteenth century, however, opium was not only confined to people who traveled to the Orient. On the contrary, the whole of English society was engaged with drug. Opium as a representation of the Orient had a significant role in evolving the plot. Its relation to the mysterious disappearance of the Moonstone emphasizes the idea of opium as an Oriental connotation to the cursed Diamond. At the time when Franklin finds no explanation for the disappearance of the Moonstone, Limping Lucy (Rossana's friend) appears with a letter from Rosanna to Franklin. Before she commits suicide, Rosanna writes her own account of the disappearance of the Moonstone. She declares to Franklin that he was the one who had stolen the Diamond since she had found the paint stain on his nightgown. This leads him and Bruff to question Rachel about this. Rachel admits that she had seen Franklin entering her bedroom and taking the Diamond. At Frizinghall, Franklin remembers a letter that Betteredge had given him. In the letter, doctor Candy also requests Franklin to see him because the doctor wants to inform him of something happened on the night of the birthday. However, Franklin finds the doctor to be suffering from delirium and unable to remember what exactly he wanted to say. Ezra Jennings tries to help Franklin by predicting what the doctor might want to say to Franklin. Jennings reveals to Franklin that he is writing "a book on the intricate and delicate subject of the brain and the nervous system" (Collins, 1998, p. 374). Jennings has captured Candy mumbling about Franklin. So Jennings promises to help Franklin to prove his innocence in relation to the theft of the Diamond.

Franklin confesses to Jennings that he suffered from bad sleep especially in Rachel's birthday night and Mr. Candy asked him to submit to "a course of medicine" (Collins, 1998, p. 81). This did not please Franklin who believed that medicine was simply "groping in the dark" (Collins, 1998, p. 81). From Candy's mumblings, Jennings proves that the doctor had given Franklin a dose of opium at that night. Consequently, Franklin became unconscious, so when he took the Diamond he was not aware of his own actions. Jennings realizes that the doctor gave Franklin a "dose of laudanum" on the night of the birthday party (Collins, 1998, p. 387). Jennings tries to explain to him the effect of opium on behavior. He also gives Franklin passages from Doctor Elliotson's Human Physiology and De Quincey's Confessions of an English Opium Eater ${ }^{3}$ that shows cases of a drunkard and opium-eater.

Integrating De Quincey's Confessions, which presents an account with opium in three different stages, and "The English Mail-Coach" which unfolds the idea of nationalism in England, allows us to understand how Collins used opium as an imperial allusion to India. In "The English Mail-Coach”, De Quincey finds that when the prevailing belief of nationalism is understood as something inherited it creates a "painful strain" (Osborne, 2010, p. 57). That is because "speed, power and progress as the foremost traits that define the Englishmen and his mail-coach" impose on people "unachievable goals for becoming a true Englishman" (Osborne, 2010, p. 40-1). Therefore, and in order to fill the gap of inadequacy, De Quincey retreated from society to opium.

De Quincey thought that opium would provide him with security. However, he realizes that opium produces "further strain" (Osborne, 2010, p. 58). The opium-eater's mind becomes more confined with the idea of Englishness that he found himself unable to achieve. Instead of overcoming the "crocodile" which represents "excessive appetite, 
hypocrisy, violence, and, most predominantly, alterity", De Quincey's mind has been "imperialized" with the ideals of Englishness. Such a result of using opium explains Franklin's increased strain that develops after the looting of the Moonstone from Verinder's house. His mind becomes more acquainted with the English mind that he has rejected. Opium imposes on him the idea of the 'Other' which he can recognise as a prejudice, since it urges him to throw accusations at 'Others' depending on their backgrounds. However, Franklin's situation differs from that of De Quincey, whose resorting to opium resulted in 'imperializing' his mind. Franklin overcomes this situation when he traces the truth behind the theft. This can be taken as Collins' defense of the 'Other' and the Orient over the Empire.

Actually, there are various other kinds of addiction in the novel that have an oriental origin. There is opium, tobacco, money, and religious addictions. Each of these addictions has an allusion to the English society corrupted by colonizing the Orient and outrageous British behaviour in India by embezzling the Hindoo idol. Each addiction represented an English institution. Opium and tobacco embody the political institution of the Empire. As this paper indicates above, both the opium and tobacco trade had flourished because of Britain's Oriental colonies. Betteredge is an example of the British political institution. He shows in the novel how he advocates the English colonial and imperial model. This was through his acquaintance with Robinson Crusoe and the tobacco which he is never without: "I kept my spirits from sinking by sticking fast to my pipe and my Robinson Crusoe" (Collins, 1998, p. 189). The British colonies in East, India, had increased the British income from the opium and tobacco trade as an example, and therefore increased people's concern to increase their fortune, or in a more accurate sense, people's greed. Greed is firstly shown by Herncastle while stealing the Moonstone. It develops throughout the novel where several characters become occupied with avarice. With the increase of their fortune, the English people moved to develop the scientific field and ignored religion. In the novel religious people are portrayed as more corrupted than ordinary people. Miss Clack insists that the devil exists within Lady Verinder and therefore she should be purified. However, Miss Clack could not be a model for other ladies.

\subsection{The 'Other' in The Moonstone}

Both the detective and the sensational novel are based on a criminal who represents the 'Other'. Therefore, they evoke the idea of the 'Other' in order to create the settings of the crime because criminals differ from 'Us'. Wilkie Collins' novel, The Moonstone, is filled with the Imperial notion of the 'Other'. However, Collins offers a clever representation of the 'Other' that allows the reader to judge whether there really is the notion of the 'Other', or whether it is merely a fabrication and stereotyping of an 'Other'. Such an approach serves the notion that Wilkie Collins has a positive attitude of the 'Orient'. Collins has offered three main attitudes towards the other in the novel. These attitudes are embodied and transformed by Gabriel Betteredge, Franklin Blake and Mr. Murthwaite which the following part of this paper will explore.

Betteredge is the steward of Lady Verinder's house. His narration is the longest compared to the other narrators. As stated previously, Betteredge is obsessed with Daniel Defoe's novel Robinson Crusoe. According to James Joyce, Robinson "is the true prototype of the British colonist" (Melani, 2013, para. 16). In The Moonstone, Betteredge parallels Robinson as an advocate of colonialism and Imperialist principles. He is just like Robinson in reflecting the "the whole Anglo-Saxon spirit ... the manly independence; the unconscious cruelty; the persistence; the slow yet efficient intelligence; the sexual apathy; the practical, well-balanced religiousness; the calculating taciturnity" (Wilson, 2014, p. 90). Such spirit encourages the idea of differentiating between 'Us' (British) and the 'Other' (Orient). Betteredge's representation of the 'Other' has two dimensions. One indicates the foreign, anyone who differs from the Victorian. The other represents the 'Other' in terms of feminist orientalism.

Betteredge is concerned with establishing the ideal English home in the novel. He preserves fixed relationships in Lady Verinder's house until the "quiet English house [is] suddenly invaded by a devilish Indian Diamond" (Collins, 1998, p. 46). Betteredge personifies the Moonstone when giving it the quality of an invasion. Moreover, this "devilish Indian Diamond" can also destroy and estrange the "quiet English house" which is the core of the English nation. Therefore, it has the ability to destroy the whole nation of England. Betteredge also emphasizes that the "cursed Indian jewel has misguided everybody who has come near it" (Collins, 1998, p. 304). The Moonstone here is not a mere gem; rather it represents India. Such representation shows the wariness of Englishmen to the colony's invasion of Britain. What is more, Betteredge's wariness is increased by the appearance of the "three mahogany-coloured Indians, in white linen frocks and trousers looking up at the house" (Collins, 1998, p. 29). Although they seem to be from a prestigious background, they remain from the 'Other' that Betteredge disdains. He describes them as "mahogany-coloured Indians". Mahogany represents the Indians' skin colour, which shows that they are from races which seem worth less than white Englishmen. The metaphor 'mahogany-coloured' is also related to the exotic commodity mahogony that Britain used to trade in during the $18^{\text {th }}$ and the $19^{\text {th }}$ century (Killingray, 2004, p. 30).

Betteredge's striking and biased judgments towards other people make him more than a mere steward in Verinder's house. His descriptions of other characters represent his negative attitude towards the 'Other'. Betteredge emphasizes the foreign colour of Franklin. This side of Franklin teases Betteredge because Franklin has none of the English uniqueness. Betteredge portrays him as a person that can adopt anything from any place. This is because he left England at a serious age "when we are all of us most apt to take our colouring, in the form of a reflection from the colouring of other people, he had been sent abroad, and had been passed on from one nation to another, before there was time for any one colouring more than another to settle itself on him firmly" (Collins, 1998, p. 55). Betteredge believes that 'Others' colouring has impacted Franklin personality. It loses him the uniqueness of being an English person especially since 
Britain at that time was known as 'the Empire on which the sun never sets'. Therefore, the 'Other' in Franklin's character decreases the glory of the Empire.

Franklin's experience in foreign lands makes all his foreign sides are "jarring with each other" (Collins, 1998, p. 55). Betteredge explains that "[h]e wrote a little; he painted a little; he sang and played and composed a little-borrowing, as I suspect, in all these cases, just as he had borrowed from me" (Collins, 1998, p. 29). Although this allows Franklin to be a "universal genius" it is a mere "borrowing" and to borrow from the 'Other' means nothing for Betteredge (Collins, 1998, p. 29).

Murthwaite, well known for traveling to India, is another character that has a relationship with the foreign. Although he is an Englishman, his traveling and strong acquaintance with India does not please Betteredge to a great deal. Betteredge attributes Oriental characteristics to Murthwaite, describing him as "a long, lean, wiry, brown, silent man. He had a weary look, and a very steady, attentive eye ... I doubt if he spoke six words or drank so much as a single glass of wine, all through the dinner" (Collins, 1998, p. 77). All such traits create an aura of mystery and enigma about Murthwaite.

Ezra Jennings is another character that Betteredge disdains because of his mysterious background. Betteredge's point of view towards him is more racist and stereotyped. Jennings's background makes Betteredge less confident of his honesty or ability to treat people. Such judgment is held because of Jennings's appearance which stands against him and never supports him. His "piebald hair, and the gipsy complexion" and his "ugly...name" make Jennings less loved among people as Betteredge believes (Collins, 1998, p. 327). His attitude is completely racist because he depends purely on his appearance for his judgment.

Although Betteredge is considered to stem from a lower class his rooted idea of Englishness allows him to pass judgments on anyone who has a relationship with the 'Other'. He believes in the perfection and superiority of the Englishman even above any other European nation when he states that he cannot bear any "foreign gibberish" (Collins, 1998, p. 55). Betteredge's ideal character is Godfrey, who he considers to be the "finest man" among the birthday guests (Collins, 1998, p. 66). Moreover, Godfrey is "the most accomplished philanthropist ... that England ever produced" (Collins, 1998, p. 67). Apparently, Betteredge has a prejudiced attitude towards the 'Other', specifically to anyone that represents sympathy to the Orient.

There is a variation in attitudes towards the Orient in Collins' novel. Franklin, who analyse incidents objectively, for instance, represents a positive attitude and way of thinking towards the 'Other', meaning the Orient. His education in foreign countries, German, French, and Italian institutions, has increased the sophistication of his way of thinking. Instead of thinking inward only and from personal attitudes, Franklin has introduced "subjective-objective" thinking in the novel and particularly in his narration. 'Subjective-Objective' dichotomies of thinking permit Franklin to be openminded and to analyze incidents from various perspectives. Franklin thinks that Betteredge's subjective thinking distances him from the truth. That is because of the "English narrowness and prejudice" (Collins, 1998, p. 181). Franklin does not disdain the Indians' devotion to their religion. However, he finds in their self-sacrificing a remarkable trait that only exists in the "Oriental races" (Collins, 1998). A justification Franklin tries to deliver for his English fellow to not accuse the Indians for their behaviour in pursuing the Diamond.

The idea of certain chosen servants of an old Hindoo superstition devoting themselves, through all difficulties and dangers, to watching the opportunity of recovering their sacred gem, appears to me to be perfectly consistent with everything that we know of the patience of Oriental races, and the influence of Oriental religions. (Collins, 1998, p. 51)

Moreover, the hocus-pocus the Indians practice does exists "[i]n our country, as well as in the East" (Collins, 1998, p. 61). Betteredge thinks it is an Oriental thing only as and therefore disdains it.

The third attitude towards the Orient is more likely to be a neutral one and is represented by Mr. Murthwaite. He is a famous traveller to India and "had penetrated in disguise where no European had ever set foot before" (Collins, 1998, p. 77). His travelling to the East allowed him to better understand the Orient, specifically India. He became more excited and accustomed to Indians culture and religion. This understanding of Indian culture corrected the English prejudice towards the Brahmins. Murthwaite knows well what the Diamond really means for the Hindoo religion. Moreover, he is able to identify the three Brahmins, unlike Betteredge who thought them mere jugglers.

Although the Verinder household does not inform Murthwaite of the Diamond that was stolen by Herncastle, he notices that there is sacrifice in the Brahmins' behavior when pretending to be jugglers:

Those men are high-caste Brahmins. I charged them with being disguised, and you saw how it told on them, clever as the Hindoo people are in concealing their feelings. There is a mystery about their conduct that I can't explain. They have doubly sacrificed their caste - first, in crossing the sea; secondly, in disguising themselves as jugglers. In the land they live in that is a tremendous sacrifice to make. There must be some very serious motive at the bottom of it, and some justification of no ordinary kind to plead for them, in recovery of their caste, when they return to their own country. (Collins, 1998, 83).

For Murthwaite, the Brahmins' behavior in devoting their life to get back the Diamond makes them "a wonderful people" (Collins, 1998, 85). He clearly notices that they would not act in that way if they were not offended in their 
religion, unlike Betteredge who resists by keeping opinion of the Brahmins as "a set of murdering thieves" (Collins, 1998, 85). Remarking 'thieves' and not people is still read as a connotation to the 'Other' who are different from 'Us' especially in a detective or sensational novel. Murthwaite's long acquaintance with the East makes him tired of the monotony of life in England. He finds his interest in India and particularly in the Hindoo religion.

\section{Wilkie Collins' Orientalism}

Wilkie Collins' novels are well known for their mysterious and alien settings. Such representations stem from "Collins's interest in 'others' [that] is...evident in the way his fiction engages with issues of race and empire, and in his depiction of exiles, including that diverse London community of exiles and fugitives from the social upheavals of nineteenth-century Europe" (Pykett, 2005, 138) .In The Moonstone, Collins integrates an extremely exotic place (India) with a decidedly non-exotic English house. In such integration Collins represents a different attitude towards the 'Other' which is in this novel the Orient than the 'Other' as another European country, such as in The Woman in White.

Collins's representation of the Orient, and in this novel the Brahmins, tries to offer the reader a better understanding of the Brahmins. The novel represents the conflict between the Brahmins' spirituality and English materiality. Collins approaches the clash between the spiritual values of the Brahmins and the material concerns of the English house in two different ways. The first is the value of the Moonstone for the Brahmins on one hand and on the other hand its value for Herncastle and the English people. For the Brahmins the Moonstone is a pillar of their Hindoo religion. Therefore, its spiritual value is "priceless" since it represents the moon god. On the other hand, the English find the Moonstone a "precious jewel" for "which would be, collectively, worth more money than the large - but imperfect single stone" (Collins, 1998, p. 48, 51). For the English, the Moonstone is worth nothing other than money and, except for Murthwaite, they find the Brahmins' quest to retrieve it meaningless. The misunderstanding of the value of the gem to the Brahmins makes the English people consider it as a mere "old Hindoo superstition" (Collins, 1998, p. 51).

The other way of contrasting the spirituality and materiality is the value of Robinson Crusoe to Betteredge when comparing it to the value of the Moonstone to Brahmins. The Brahmins believe in the Moonstone because it is a source of purification from sin. They find it an immortal artefact for heavenly life. On the other side, Betteredge's belief in Robinson Crusoe, who embodies imperialism, represents his belief in Empire and dominating the 'Other', which causes violence. What is more, Katie Lanning explains that although Robinson Crusoe has a "sentimental value to Betteredge, he cannot 'detach' its "value as a physical market object" when suggesting to the readers to buy the novel Betteredge "treat [it] ... as a commodity" (Lanning, 2012, p. 2). In this sense the book's value is associated to its materialistic sense also.

Collins reveals to the reader that although the Moonstone is precious, its spiritual value for the Brahmins is more important, and indeed is 'priceless'. On the other hand, the Englishman associates material value to the spiritual object. Depiction as that emphasizes Collins positive attitude towards the Brahmins by showing that their way of valuing is superior.

Another way that Collins uses to justify the Oriental is to show that both Easterners and the Westerners are similar, especially in terms of the nineteenth-century household, according to the prevailing view of Eastern women at that time. The Oriental woman is usually portrayed as submissive to patriarchal authority. Such portrayal is also read through Collins' novel which is represented through Betteredge and Godfrey. Godfrey is seen as

A ladies' man by temperament ... Female benevolence and female destitution could do nothing without him. Maternal societies for confining poor women; Magdalen societies for rescuing poor women; ... he was vicepresident, manager, referee to them all. Wherever there was a table with a committee of ladies sitting round it in council there was Mr. Godfrey at the bottom of the board, keeping the temper of the committee, and leading the dear creatures along the thorny ways of business, hat in hand. (Collins, 1998, p.67)

This passage shows how Godfrey dominates the women of his community. It gives him the permission to rule over them wherever he finds it pleasing to do so. Although he is seen as benevolent, he still keeps the relation of authorizer over these women when he is portrayed as a "vice-president, manager, [and a] referee" (Collins, 1998, p. 67). However, Penelope, Betteredge's daughter, sees that Godfrey is "[a] nasty sly fellow" and she finds Rachel's rejection of marrying him a victory for women because she is the only "one woman in the world who can resist Mr. Godfrey Ablewhite" (Collins, 1998, p. 75) Collins tries to prove that the patriarchal dominance exists also in nineteenth century society. In that way he draws both the East and the West together.

A doubling motif is another way to draw the similarities between the West and the East which Collins tries to achieve. This motif is used to address the reader in the importance of pursuing knowledge and truth in order to get rid of any stereotyping and falsifications. The main doubling motif in this novel is between the three Brahmins and the three English investigators, Franklin, Jennings and Murthwaite. The Brahmins are investigating the theft of the Moonstone in order to return it to India. They know exactly who the thief is by the use of 'hocus-pocus' which seems valid in this novel. On the other side, Franklin, Jennings and Murthwaite are also investigating the theft of the Moonstone. Franklin becomes so concerned to find the thief; this makes each of Jennings and Murthwaite to become involved in this investigation also. This investigation reveals that the thief is an Englishman, Godfrey. The nearer Franklin, Jennings and Murthwaite become to the truth, the better they understand the innocence of the Orient. Detecting the truth, Wilkie Collins suggests, offers a better understanding of the Orient. 
Although Collins offers a good understanding of the Brahmins, the novel reveals misunderstandings toward Indian Muslims. Krishna Manavalli (2007) explains that Wilkie Collins' novel portrays a good example of "the nineteenthcentury colonial versions" since it "idealized Hindu subjects ... and ... marginalized Muslim rulers" (p. 73). The Muslims in the Moonstone, therefore, are treated as "outsider to Indian tradition" (Manavalli, 2007, p. 73). John Reed has explained that such representation is a result of the "colonial anxiety about the Muslim threat" (Manavalli, 2007, p. 73). Therefore, "Collins's novel works to underline 'the ideological project of the British Raj, [of] the desacralization of the [Muslim]"” as a result of the British interest in Hindus at that time (Manavalli, 2007, p. 77).

\section{Conclusion}

In spite of it's undermining of, Wilkie Collins succeedes in defending the Hindu religion of the Brahmins from the British usurpers. Collins sought to "interrogate rather than empower colonialist ventures" (Munjal, 2008, p. 11). He achieved that by various techniques. One is the use of various narrators in order to detect the theft of the Moonstone. These narrators are of varied backgrounds and some of them are of colonial roots like Jennings. This helps to seek the truth from different angles. Another way to interrogate colonialists' ventures is sending death to Herncastle and Godfrey who try to destroy the Moonstone identity. Their behaviour is seen as the "spread of social and moral chaos in the English community" which can be interpreted read from Godfrey's character who pretends to be a philanthropist but he uses his work to betray two heiresses (Munjal, 2008, p. 9). Collins seeks also to "construct a discourse where the West has been seen as immoral, estranged in its individualism, and indulging in materialism without Spirit" (Munjal, 2008, p. 14). Although Herncastle knew about the holiness of the gem, he insists on taking it to England and bearing all risk for the sake of its material value.

Another way in which Collins tries to justify the Orient, specifically the Brahmins, is the way in which he constructed the novel. The prologue and epilogue are the only parts which are set in India. In the former, Collins shows the defeat of the Brahmins by the Colonizer. Collins, however, justifies such defeat by demonstrating victory to the Brahmins and the retrieval of the Moonstone. This is to show the superiority of "Indian spirituality" over the "material West" (Munjal, 2008, p. 14). This victory demonstrates the defeat of Robinson Crusoe, who represents imperialism. Robinson is a representation of an "enlightened European" who can emancipate Friday from his savagery "through assimilation into Crusoe's culture" (Dofeo, 2014). Collins reverses this notion when he portrays Murthwaite abandoning the English culture and instead assimilating Indian Brahmin culture. Such representations and techniques suggest to the reader that Wilkie Collins has adopted a positive attitude towards the Indian Brahmins.

\section{Sponsoring information}

The Research Council and Al Buraimi University College, the Sultanate of Oman.

\section{References}

Al Dabbagh, A. (2010). Literary Orientalism, postcolonialism, and universalism. New York: Peter Lang.

Battle of Plassey. (2013, January 7). Retrieved May 25, 2015, from http://www.newworldencyclopedia.org/entry/Battle_of_Plassey

Brantlinger, P. (1982). What Is "Sensational" About the "Sensation Novel"? Nineteenth-Century Fiction, 1-28. Retrieved March 9, 2011, from Jstor.

Clarke, B. (1999, June 23). Opium and Empire in Victorian Britain. Retrieved May 25, 2012, from http://www.qub.ac.uk/imperial/india/opium.htm

Collins, W. (1998). The Moonstone (S. Kemp, Ed.). London: Penguin Books.

Cook, M. (2014). Detective Fiction and the Ghost Story: The Haunted Text. England, UK: Palgrave Macmillan.

David, D. (2001). The Cambridge companion to the Victorian novel. Cambridge, UK: Cambridge University Press.

Defoe, D. (2014). Robinson Crusoe: The Complete Adventures (Vol.1 - Vol.2): (Illustrated Edition). Snowball Classics.

Heehs, P. (2003). Shades of Orientalism: Paradoxes and Problems in Indian Historiography. History and Theory, (42), 169-195. Retrieved November 12, 2011, from Jstor.

Hobsbawm, E. (1989). The Age of Empire, 1875-1914. New York: Vintage Books.

Jouhki, J. (2006). Orientalism and India. J@rgonia, 4(8), 1-20.

Killingray, D., Lincoln, M., \& Rigby, N. (2004). Maritime empires: British imperial maritime trade in the nineteenth century. Woodbridge, Suffolk, UK: Rochester, NY.

Lanning, K. (2012). 2011 VanArsdel Prize Essay Tessellating Texts: Reading The Moonstone in All the Year Round. Victorian Periodicals Review, 1(54), 1-22. Retrieved May 23, 2015, from http://www.press.jhu.edu/journals/press_releases/summaries/45.1.lanning.pdf

Lightwalla, A. (2010). 'Detective Fiction Is Always Engaged in a Veiled Form of Colonial Discourse'. Retrieved May 24, 2015, from http:/www.nottingham.ac.uk/english/documents/innervate/09-10/0910lightwalladetectivefiction.pdf

Loftus, D. (2011, February 17). The Rise of the Victorian Middle Class. Retrieved May 24, 2015, from http://www.bbc.co.uk/history/british/victorians/middle_classes_01.shtml 
McCoy, A., Read, C., \& Adams, L. (1972). The Colonial Legacy: Opium for the Natives. In The politics of heroin in Southeast Asia. New York: Harper \& Row.

Melani, L. (2013, January 26). Robinson Crusoe. Retrieved February 10, 2015, from http://academic.brooklyn.cuny.edu/english/melani/novel_18c/defoe/economic.html

Manavalli, K. (2007). Collins, Colonial Crime, and the Brahmin Sublime: The Orientalist Vision of a Hindu-Brahmin India in The Moonstone. Comparative Critical Studies, 4(1), 67-86.

Munjal, S. (2008). Imagined Geographies: Mapping the Oriental Habitus in Three Nineteenth-Century Novels. Postcolonial Text, 4(1), 1-14.

Osborne, P. W. (2010). 'Thomas De Quincey's retreat into the "Nilotic Mud": Orientalism as a response to social strain'. Published master's thesis, College of Arts and Sciences, Georgia State University, Atlanta, Georgia.

Peers, D. (2013). India under colonial rule: 1700-1885. London: Taylor \& Francis.

Pereda, M. (2009). Delacroix, Orientalism and Romanticism. Retrieved May 27, 2012, from http://evergreen.loyola.edu/brnygren/www/Honors/Romanticism.htm

Pykett, L. (2005). Wilkie Collins. Oxford: Oxford University Press.

Reddy, K., \& Gupta, P. (Eds.). (2004). Report on Tobacco Control in India. New Delhi: Ministry of Health \& Family Welfare.

Said, E. (1978). Orientalism. London: Routledge.

Särkkä, T. (2009). Hobson's imperialism: A study in late-Victorian political thought. Jyvaskyla: University of Jyvaskyla.

Sered, D. (1996). Orientalism. $\quad$ Retrieved $\quad$ May $\quad 22, \quad 2015$, from https://scholarblogs.emory.edu/postcolonialstudies/2014/06/21/orientalism/

Umunç, H. (2000, April). Civilizing the Other: Defoe's Robinson Crusoe and the British Imperial Ideology. Paper presented at 21st All-Turkey English Literature Conference, Middle East Technical University, Ankara.

Wilson, K. (2014). The island race: Englishness, empire, and gender in the eighteenth century. London: Routledge.

\section{Notes}

Note 1. Seringapatam or siege of Seringapatam (1799) occurred between the Kingdom of Mysore (Muslims) in India and British. In this siege the British East India Company achieved its dominance over India.

Note 2. "Thomas De Quincey's Confessions of an Opium-Eater also reflects the increasing fascination with the unknown. His attempt to describe an experience as unintelligible and unique as his personal opium-use results in a passionate and fairly unscientific account. De Quincey claims that the first time he used opium, "positive effects...opened before [him] in the abyss of divine enjoyment." He goes on to say that in opium he found "the secret of happiness." Opium, nor any drug for that matter, is the secret to happiness. Yet De Quincey takes advantage of our ignorance of opium to create a romantic, picturesque experience for the reader. His language is both vague and attractive to readers who have no previous experience with opium". (Pereda, 2009, para. 3) 